\title{
Elderly caring for the elderly: spirituality as tensions relief
}

\author{
Idosos cuidando de idosos: a espiritualidade como alívio das tensões \\ Ancianos que cuidan a los ancianos: la espiritualidad como alivio de las tensiones
}

\author{
Monalisa Claudia Maria da Silva', Alexander Moreira-Almeida', Edna Aparecida Barbosa de Castro' \\ 'Universidade Federal de Juiz de Fora. Juiz de Fora, Minas Gerais, Brazil.
}

\begin{abstract}
How to cite this article:
Silva MCM, Moreira-Almeida A, Castro EAB. Elderly caring for the elderly: spirituality as tensions' relief. Rev Bras Enferm [Internet]. 2018;71(5):2461-8. DOI: http://dx.doi.org/10.1590/0034-7167-2017-0370
\end{abstract}

\section{Submission: 05-15-2017 Approval: 02-01-2018}

\begin{abstract}
Objective: To investigate the forms of coping used to relieve tensions by elderly caregivers of elderly relatives and to know the type of support they receive from the Primary Health Care service at home. Method: A qualitative study with a theoreticalmethodological contribution of Grounded Theory, carried out with 10 elderly caregivers interviewed between August 2014 and January 2015. Results: Participants use primarily religious coping to deal with adverse situations that arise in their lives; they attribute to the sacred the strength to continue to age and care for another elderly person at home. Religiousness was the main coping strategy used by the participants, but little recognized by the health service. Final considerations: It is recommended that the Primary Health Care service provide greater support to these caregivers and be attentive to the spiritual dimension as an auxiliary element in the process of comprehensive and inclusive health care of these elderly caregivers.
\end{abstract}

Descriptors: Aging; Caregivers; Elderly; Spirituality; Primary Health Care.

\section{RESUMO}

Objetivo: Investigar as formas de enfrentamento utilizadas para alívio de tensões por cuidadores idosos de familiares idosos e conhecer o tipo de apoio que recebem do serviço de Atenção Primária à Saúde no domicílio. Método: Estudo qualitativo, com aporte teóricometodológico da Grounded Theory, realizado com 10 cuidadores idosos entrevistados, entre agosto de 2014 e janeiro de 2015. Resultados: Os participantes utilizam-se prioritariamente do coping religioso para enfrentar situações adversas que surjam em suas vidas; atribuem ao sagrado a força para continuar a envelhecer e cuidar de outro idoso no domić́lio. A religiosidade foi a principal estratégia de enfrentamento utilizada pelos participantes, porém, pouco reconhecida pelo serviço de saúde. Considerações finais: Recomenda-se que o serviço de Atenção Primária à Saúde proporcione maior apoio a esses cuidadores e que esteja atento à dimensão espiritual como elemento auxiliar no processo de assistência integral e inclusiva à saúde desses cuidadores idosos.

Descritores: Envelhecimento; Cuidadores; Idoso; Espiritualidade; Assistência Primária à Saúde.

\section{RESUMEN}

Objetivo: Investigar las formas de enfrentamiento utilizadas para alivio de tensiones por cuidadores ancianos de familiares ancianos y conocer el tipo de apoyo que reciben del servicio de Atención Primaria a la Salud en el domicilio. Método: Estudio cualitativo, con aporte teórico-metodológico de la Grounded Theory, realizado con 10 cuidadores ancianos entrevistados, entre agosto de 2014 y enero de 2015. Resultados: Los participantes se utilizan prioritariamente del coping religioso para enfrentar situaciones adversas que surgen en sus vidas; atribuyen al sagrado la fuerza para continuar envejeciendo y cuidar de otro anciano en el domicilio. La religiosidad fue la principal estrategia de enfrentamiento utilizada por los participantes, pero poco reconocida por el servicio de salud. Consideraciones finales: Se recomienda que el servicio de Atención Primaria a la Salud proporcione mayor apoyo a esos cuidadores y que esté atento a la dimensión espiritual como elemento auxiliar en el proceso de asistencia integral e inclusiva a la salud de esos cuidadores ancianos.

Descriptores: Envejecimiento; Cuidadores; Ancianos; Espiritualidad; Asistencia Primaria a la Salud. 


\section{INTRODUCTION}

The last half of the twentieth century witnessed a worldwide demographic transition, understood as a longevity revolution ${ }^{(1)}$. Although the timing and pace of transition are different between developed and developing countries, the framework for change is typically similar ${ }^{(2)}$. The aging process has evolved rapidly in developing countries that have experienced a rapid process of epidemiological transition $^{(3)}$. In Brazil, population projections tend to reduce youth and the aging of the population in the coming decades ${ }^{(4)}$.

Primary Health Care (PHC) has in the Family Health Strategy (FHS) the proposal for a reorganization of health care, with emphasis on the practice of continuing integral health care for the elderly, being close to the community and allowing a harmonious performance with the reality experienced by the elderly in the family context ${ }^{(5)}$. The health care network has not addressed the needs of the elderly and their caregivers. The home visit (HV) aimed at this public, for example, is not always satisfactorily performed due to the incomplete and incomplete multiprofessional team, as well as infrastructure deficiencies of the $\mathrm{BHU}^{(6)}$.

Because of the aging process, there is a probability of developing chronic sickness and/or disability. There are elderly people who, in addition to being subject to this reality, informally take care of another elderly relative at home. By becoming a caregiver, he coexists with a threat to his self-care, well-being, physical, emotional overload and social isolation ${ }^{(7)}$. The role of the caregiver has been widely explored by the researches in the area of gerontology and Collective Health, however, there is a difficulty in recognizing and a way to support the needs arising from the activities carried out by caregivers, especially from their perspective ${ }^{(8-9)}$.

The needs of the elderly caregiver of an elderly relative, especially dependents, translate into high loads of activities and stress that reflect on their physical, psychological and emotional health, with implications for both ${ }^{(10)}$. A study that evaluated factors associated with stress perceived by elderly caregivers revealed significantly elevated values in relation to pain and difficulty in self-reported sleep and poor self-assessment in relation to health ${ }^{(11)}$.

There is a considerable literature on caregivers in general ${ }^{(12)}$, however, there is a gap regarding studies on the elderly family caregiver. No systematic actions are identified with evaluation and health care of those who care for the patient, such as the "family caregiver"(13). As a result, the work they carry out is of low visibility and the support required to perform such a function is scarce. It is understood that, in order to offer care that includes the caregiver and his family member, it is necessary for the professionals to know the context of the life, culture and belief system in which they are inserted ${ }^{(14)}$.

Although the process of redemocratization of the rights of the elderly has advanced with the Federal Constitution of 1988, there is a greater vulnerability of the elderly person as the age progresses. The World Health Organization (WHO) defines the basis for a healthy aging, based on the social inclusion of the elderly, highlighting equity and integrality in access to health care, and the continued development of actions to promote health and prevent diseases ${ }^{(15)}$.
In this sense, it is relevant to know the elderly caregiver's daily life and the stress coping strategies of this significant portion of the population that has little visibility, but which plays an important role in public health: caring for the elderly in domicile, being elderly. In order to help fill this gap, it is essential that studies be developed in this area so that the voice of these elderly caregivers can be heard: what they think, what their challenges, resources and needs are.

\section{OBJECTIVE}

To investigate the forms of coping for stress relief used by elderly caregivers of elderly relatives and to know the type of support they receive from Primary Health Care at home.

\section{METHOD}

\section{Ethical aspects}

The research was approved by the Research Ethics Committee by the Universidade Federal de Juiz de Fora.

Type of study and theoretical and methodological framework

Research of qualitative nature, carried out with the contribution of Grounded Theory, which in Brazil obtained the translation of Teoria Fundamentada nos Dados (TFD). In this research, we adopted the guidance of Anselm Straus and Juliet Corbin, for whom the data collection by the researcher himself in scenario of occurrence; the analysis and the possible theory maintain a close relation between them, allowing, through codification procedures, to construct instead of testing a theory ${ }^{(16)}$.

We chose this method because it allows the substantive theorization about the phenomenon of home care to the elderly by an elderly family member, with the merit of contributing to professionals who need knowledge to deal with this problematic and emerging situation in the current context care of the elderly. In this approach, the primary objective is the discovery of the variables and not their control having one of its characteristics the grounding of the concepts in data. It seeks to balance researchers' science and creativity, which is essential, "to nominate categories, to ask encouraging questions, to make comparisons and to draw an innovative, integrated and realistic scheme of raw, disorganized masses of data, which can generate assumptions or hypotheses"(16).

\section{Methodological procedures}

\section{Study setting and participants}

The survey was conducted in the Northern Zone of a municipality of Minas Gerais, whose estimated population for the year 2014 was $550,710^{(17)}$, and $13.7 \%$ were 60 years or older ${ }^{(18)}$. According to the Brazilian Institute of Geography and Statistics (IBGE) ${ }^{(19)}$, the Northern Zone had 85,615 inhabitants distributed in an extensive urban area, located far from the center of the city, where the main institutions of care and attention to the health of the elderly.

Ten elderly caregivers of another elderly person of the family residing in the area of the Basic Health Unit (BHU) participated in the study. 
The inclusion criteria were: age $\geq 60$ years; be primarily responsible for the care of an elderly family member at home; live with him and reside in the area covered by BHU of the Northern Zone of the municipality studied. No testimonial was excluded because the contents of all were sufficient to meet the research objectives.

The sampling group was constituted by convenience, indicating the nurse, community health agent $(\mathrm{CHA})$ of the $\mathrm{FHS}$ or merchants of the neighborhoods surveyed, at the request of the researcher visiting the neighborhoods. The sample size and final composition were determined by the saturation of the codes during the data analysis process ${ }^{(16)}$.

\section{Collection and data organization}

Data collection was performed between August 2014 and January 2015, through a semi-structured interview, during the HV, previously scheduled from the contact with the neighborhood informant/BHU.

To guide the interview, questions were asked about aging and becoming a caregiver, how the institutionalized support received when caring for the other and how to seek relief from everyday tensions.

Each testimony took on average 55 minutes, recorded with digital recorder, transcribed and analyzed before the next interview. During the interview, there were no other people in the (private) room, other than the informant and the researcher, in order to leave them free to express themselves.

All the caregivers contacted agreed to participate in the research and signed the Informed Consent Term. To ensure anonymity, informants were identified by using biblical names.

\section{Data analysis}

For the textual edition of the empirical data, software was used, the program OpenLogos $^{\circledR}$, version 1.0.2. The data analysis was concomitant with the data collection and in three distinct phases that complement each other in the data integration: open, axial and selective coding. In open coding, the data were analyzed line by line and compared by similarities and differences, generating a codification of the data. In the axial coding, for each code of the previous phase a related concept was developed in order to identify it transversally to the data collected, establishing a preliminary analogy between categories and subcategories. In the selective coding, the integration and refinement of the categories occurs so that the results of the research make it possible to reach the central category of the study and through the consistency of the data, validate the theory ${ }^{(16)}$.

Based on the identified categories and established theoretical relations, it was possible to develop an analytical and explanatory process of the actions and interactions that formed the process of caring for an elderly person by an elderly family caregiver.
We can find the categories: "Elderly caregiver who cares daily for an elderly person at home and the health team" and "The spiritual dimension influencing the life and process of caring for the elderly family caregiver".

\section{RESULTS}

The age of family caregivers surveyed ranged from 60 to 90 years. Three caregivers did not live with the companion; eight were women, distributed under wives and daughters; two were responsible for the care of another dependent relative, in addition to the elderly. Their income is the source of retirement or pension, and two caregivers do not have any type of personal income, depending on the children or family members they care for. It should be noted that all caregivers had at least one chronic non-communicable disease (Chart 1).
Chart 1 - Introducing the caregivers

\begin{tabular}{|c|c|c|c|c|c|c|}
\hline Name & Age & $\begin{array}{c}\text { Gender } \\
*\end{array}$ & $\begin{array}{c}\text { Marital } \\
\text { status } \\
* *\end{array}$ & $\begin{array}{c}\text { Relationship } \\
\text { with the } \\
\text { cared-for }\end{array}$ & $\begin{array}{c}\text { Family } \\
\text { Nucleus }\end{array}$ & Religion \\
\hline Adameire & 90 & $\mathrm{~F}$ & $\mathrm{M}$ & $\begin{array}{c}\text { Husband (93) and } \\
\text { daughter (67) }\end{array}$ & $\begin{array}{c}\text { Husband and two } \\
\text { daughters }\end{array}$ & Lapsed Spiritist \\
\hline Isabel & 60 & $\mathrm{~F}$ & $\mathrm{~W}$ & Mother (97) & Mother & Lapsed Catholic \\
\hline Dina & 61 & $\mathrm{~F}$ & $\mathrm{D}$ & Mother (86) & Mother & Lapsed Catholic \\
\hline Lia & 60 & $\mathrm{~F}$ & $\mathrm{D}$ & $\begin{array}{c}\text { Mother (94) and } \\
\text { brother (57) }\end{array}$ & $\begin{array}{c}\text { Mother, brother } \\
\text { and daughter }\end{array}$ & Lapsed Catholic \\
\hline Joshua & 70 & $\mathrm{~F}$ & $\mathrm{M}$ & Father (93) & Husband e Father & Catholic \\
\hline Gedeão & 61 & $\mathrm{M}$ & $\mathrm{M}$ & Wife (74) & Wife & Evangelical \\
\hline Talita & 79 & $\mathrm{~F}$ & $\mathrm{M}$ & Husband (81) & Wife and daughter & Catholic \\
\hline Ruth & 66 & $\mathrm{~F}$ & $\mathrm{M}$ & $\begin{array}{c}\text { Husband (86) } \\
\text { Husband and } \\
\text { stepson }\end{array}$ & Evangelical \\
\hline Samuel & 79 & $\mathrm{M}$ & $\mathrm{M}$ & Wife (74) & Wife & Catholic \\
\hline Eunice & 73 & $\mathrm{~F}$ & $\mathrm{M}$ & Wife & Husband & Lapsed Evangelical \\
\hline
\end{tabular}

Nota - Gênero* $-F=$ Feminino $/ M=$ Masculino; ${ }^{* *}$ Estado civil $-D=$ Divorciado $/ C=$ Casado $/ \mathrm{V}=$ Viúvo/a.

\section{Category 1: Elderly caregiver who cares daily for an elderly person at home and the health team}

According to the participants, the care offered has not provided them with care needs and, in some cases, they do not have a FHS as a reference. Thus, without proper support, care is exclusively on the elderly caregiver and with sporadic actions of the health team. Caregivers, when asked who they are cared for, did not cite the $\mathrm{FHS}$ as a reference. However, they reported receiving $\mathrm{CHA}$ visits:

It will be two and a half years since we are living here, except the CHA, no one came, no doctor, no nurse. [...] After I moved here, they have never done proper follow-up, neither for me nor for her, they don't do it. (Gedeão)

In this research, we identified the importance of the practice of active listening with the elderly. Participants reported feeling 
"valued and relieved" by qualified listening. When this practice occurred, during the interviews with the researcher, all the caregivers explained this through the lines, as in the following examples:

I would like to thank you for coming, for listening to me, oh! No one has ever stopped to listen to me, [...] if you want to come back, you will always be very welcome. (Dina)

It's the first time anyone has ever listened to me. How good it is! Thank God, when you talk to a person you feel new again [...] it's always good to talk to people who listen to you, talking helps to solve problems. (Gedeão)

According to the reports obtained, the elderly caregiver, who is suffering from chronic diseases and has the role of caring fully, sometimes alone at home. Moreover, this elderly ends up being deprived of activities outside home, due to the difficulty of lack of a companion to replace it in the care provided to the elderly relative, which restricts their space and their social network:

God gives me strength, because I live in a prison without walls [...]. He, despite being this way, does not stand still, and I can't leave him alone [...] I can't go to the doctor because it is very difficult to schedule, so I end up buying the medicine on my own. (Ruth)

\section{Category 2: The spiritual dimension influencing the life and process of caring for the elderly family caregiver}

The reports of the present study demonstrated that the elderly often practice intrinsic religiosity, which provides mechanisms of adaptation and strength for coping in times of crisis:

I don't drink a drop of water in the morning, while I don't thank God, I thank for my life, the lives of my children, my husband. [...] I believe that God gives strength, and everyone, everything that we meet is due to his will, if we fail to understand or desire his presence with us, we have no life, our life is the divine light, is God's strength. (Adameire)

My strength comes from God, the day I don't pray, I feel like I'm missing something, it's the faith I have in God, regardless of family and anything, what moves is the faith I have in God. He's always in my life, always at his discretion. (Samuel)
According to the participants, the fragilities arising from the aging process, identified on a daily basis can be relieved when one believes in God. Prayer was the main religious practice that emerged from the experiences of all of them:

A prayer helps a lot, because we get closer to God as we talk to him, right? And we pray. (Joshua)

Only for God, you have to have a lot of faith, ask for much protection to him. This is what I do every day in the morning. (Lia)

On the other hand, in addition to prayer, all participants reported the importance of frequent religious practice in cults and other religious commitments, as a support in coping with misfortunes that arise during life:

I go to church every Sunday, when I don't go on Saturday, I go on Sunday. (Isabel)

I watch Father Marcelo's mass on TV and I go to church every week, because Father Marcelo's Mass is only for those who can't go to church. (Samuel)

When they experienced a recovery in health, considered impossible, one of the participants credited the event to prayer and faith:

Well, I started taking caring for him when he had stroke, [...] he was hospitalized for many months and was practically inactive. The doctor, when he saw him walking again, said it was a miracle, but prayer has power [...], and, thanks God, I take care of him today. (Ruth)

From the data previously described, we could see that the participants seek help in a transcendent force to persevere in their way, aging and caring for elderly people, at home. In their statements, there was presence of the spiritual religious coping in the confrontation of the adversities of life. Chart 2 shows the positive coping strategies used by the caregivers participating in this study, in their daily lives. The types of coping strategies were based on the Religious-Spiritual Coping Scale (SRCOPE scale) $)^{(20-21)}$.

Chart 2 - Coping strategies commonly used by caregivers participating in the study

\begin{tabular}{|l|l|l|}
\hline Factors & Strategy used & Participants who used them \\
\hline \multirow{2}{*}{ Actions for spiritual assistance } & Attending religious or spiritual services & $\begin{array}{l}\text { Adameire, Isabel, Dina, Lia, Joshua, } \\
\text { Gedeão, Talita, Ruth }\end{array}$ \\
\hline Helping others & Praying for the well-being of others & Everyone \\
\hline \multirow{5}{*}{ Positive attitude towards God } & Seeking love and protection of God & Everyone \\
\cline { 2 - 3 } & Believing that God is always with them & Everyone \\
\cline { 2 - 3 } & Searching force, support and guidance in God & Everyone \\
\cline { 2 - 3 } & Praying to God that everything will be well & Everyone \\
\cline { 2 - 3 } & Feeling God is working for him & Everyone \\
\cline { 2 - 3 } & Establishing a greater connection with God & Everyone \\
\hline \multirow{2}{*}{ Actions for Institutional Assistance } & Listening and/or singing religious songs & $\begin{array}{l}\text { Adameire, Isabel, Dina, Lia, Joshua, } \\
\text { Gedeão, Talita, Ruth, Eunice }\end{array}$ \\
\hline
\end{tabular}




\begin{tabular}{|l|l|l|}
\hline \multirow{5}{*}{ Factors } & Strategy used & Participants who used them \\
\hline \multirow{5}{*}{ Actions for Institutional Assistance } & $\begin{array}{l}\text { Performing spiritual acts or rites (any action } \\
\text { specifically related to your belief: sign of the } \\
\text { cross, confession, prayer of the rosary, fasting, } \\
\text { purification rituals, citation of proverbs, } \\
\text { intonation of mantras, psychography, etc.) }\end{array}$ & Everyone \\
\cline { 2 - 3 } & $\begin{array}{l}\text { Participating in religious or spiritual practices, } \\
\text { activities, or festivities }\end{array}$ & Isabel, Joshua, Gedeão, \\
\cline { 2 - 3 } & $\begin{array}{l}\text { Going to a religious temple, seeking the house of } \\
\text { God }\end{array}$ & Isabel, Joshua, Gedeão, Ruth, Samuel \\
\cline { 2 - 3 } $\begin{array}{l}\text { Personal search for spiritual } \\
\text { knowledge }\end{array}$ & $\begin{array}{l}\text { Seeking help in sacred books (Bible and other) } \\
\text { / reading spiritual/religious teachings books to } \\
\text { understand and deal with adversity }\end{array}$ & Everyone \\
\cline { 2 - 3 } & $\begin{array}{l}\text { Watching religious programs or movies } \\
\text { dedicated to spirituality }\end{array}$ & Everyone \\
\hline
\end{tabular}

\section{DISCUSSION}

Participants having to take care of the elderly family member alone have mentioned the lack of support from FHS professionals and the lack of qualified listening. In this sense, the institutional support of a multiprofessional team is relevant.

The daily life of elderly people who take care of an elderly relative must be recognized by professionals working at PHC, currently defined as the preferred door of the health system, since it plays an essential role in Health Care, in the support to these caregivers and to elderly relatives of those who they care. However, what was perceived with the data analysis was a deficit in the health needs of the caregiver-elderly and elderly-care binomial, pointed out by those who seek care in the network services, the BHU and the FHS team through consultations and especially in HV. The implementation of the elderly health care network has still been slow and fragmented; incomplete FHS with difficulty in selecting families/elderlies who really need home care ${ }^{(6)}$.

Scientific literature shows that the task of caring for dependent elderly people in the home can generate adverse effects to the caregiver, causing negative impacts and physical, emotional, social and financial burden. Thus, there is a need to develop programs to prevent these effects and to work towards the quality of life of the caregiver. It is relevant to research and implement practices with better evidence of cost-effectiveness, such as: in which situations HV should be done, how caregiver training should be done and what tasks should be trained ${ }^{(10,22)}$.

The health professional can evaluate the support network of the elderly and maintain the home monitoring for the supervision of the care, in addition to offering appropriate support. The importance of the family is ensured, but care must be taken to ensure that it does not take care of itself but is aided by $\mathrm{PHC}$ and a network of social relations, serving as support in times of need and crisis $^{(7)}$. In this way, we should highlight the importance of therapeutic listening, dialogue process and language adaptation during the care of the elderly. Assistance based on the interpersonal relationship with a view to the integral care of the human being will favor the attendance of the health needs of this population, through the speech, listening, connection and negotiation ${ }^{(5)}$.

In order for the FHS to develop a process of construction of new practices, it is imperative that the professionals involved articulate an integrated, interdisciplinary dimension, a knowledge relationship and articulation between knowledge and common care for the development of teamwork ${ }^{(7)}$.

Participants are primarily concerned with spiritual religious coping, defined as the use of religious beliefs and behaviors aimed at facilitating problem solving, preventing or relieving the negative emotional implications experienced in an emotionally critical circumstance ${ }^{(23)}$. Respondents often stated that, with the support of family members, the process of caring for the other becomes lighter; but without the fulfillment of their spiritual needs, there would be a weakening, relative to their empowerment. They relate to discover in God the strength to face life and the care of the other, as well as to the very consciousness of aging. It was unanimous among the study participants the importance of religiosity and spirituality in their lives.

The interface between spirituality and health is a relatively new area of research, but it is developing rapidly. Research on R/S (Religiosity/Spirituality) shows great influence of this dimension on the physical and mental health of individual ${ }^{(24)}$. Although the impact of R/S is often positive on health and coping with adversity, it can also be negative if it is associated with poorer health indicators ${ }^{(25)}$.

Spirituality has its meaning, the search for the meaning of life ${ }^{(26)}$, and has always been a scenario contradictory to scientific rationality. With the recognition by the $\mathrm{WHO}$ of the importance of spirituality for quality of life, it has come to be considered an important field of evaluation and health promotion in all phases and ages. And in the stage of aging, spirituality comes from the ability to endure mishaps, difficulties and losses intrinsic to this phase, where there is a diversity of spiritual experience, having in common the recognition of its relevance to aging with quality of life(27).

In a study to investigate the spiritual-family experience and its influence on health among elderly couples, participants reported that family spirituality improves communication and strengthens family relationships, corroborates family health, 
improves emotional well-being, development of healthy new behaviors, as well as providing healing experiences ${ }^{(28)}$.

There is evidence ${ }^{(26,29)}$ that $R / S$ are factors usually integrated positively to psychological well-being, satisfaction in living, happiness, improvement of physical and mental health, in addition to being correlated with decreased morbidity and mortality. In the last decades, literature reviews have been published on the relationship between R/S and physiological processes, including cortisol decrease ${ }^{(30)}$ and increase in immunological factors $^{(31)}$. These findings have also been replicated in Brazilian elderly $^{(32-33)}$. Consistent with the results of the present study, in which participants believe that seeking God's help can help them cope better with difficulties and tensions, it has been identified that prayer can affect their lives over the years ${ }^{(34)}$. In another study, caregivers reported that one form of care is faith, when $98 \%$ of them claimed to have a religious belief. For them, faith is a way of caring for oneself that promotes strength and hope to continue in the care of the dependent elderly relative, in addition to the other daily tasks ${ }^{(35)}$.

In a literature review, we examined the effects of R/S on health, such as cognitive functioning, survival strategies, and quality of life in elderly people with dementia. The results highlight possible benefits of R/S for health, from different aspects, among them, the use of spirituality or faith in everyday life, allowing people to develop coping strategies and acceptance of their illness, maintain their relationships, hope and find meaning in their lives, thus improving their quality of life ${ }^{(36)}$.

The health professional, by rephrasing his practice, according to the ideology of care proposed for the FHS, can access the spiritual dimension as a support for the different therapies, strengthening the perspective of integral care, with quality and resolution. When the professional turns to the values, beliefs and spirituality of the person cared for, through the reception with qualified listening, it makes possible the understanding, the hope, the relief of the pain and the suffering of the user.

In order for the health professional to be able to access the spiritual dimension of the user, it is essential to have a reliable link, in addition to identifying the right moment to approach the subject, and to make use of common sense. This approach may occur during the anamnesis, quite naturally, and although there is no "recipe" for the spiritual approach, it is considered a great opportunity the moment when the patient himself brings the matter to the surface, demonstrating the importance that it exercises in your life ${ }^{(37)}$.

However, many health professionals still find it difficult to address the issue of patients' $\mathrm{R} / \mathrm{S}^{(38)}$. Therefore, several publications have addressed how to integrate R/S in an ethical and responsible way, based on scientific evidence, in clinical care ${ }^{(36,39)}$. In order to facilitate the approach of spirituality for health professionals, tools have been developed to obtain the spiritual history of the patient. When lack of time is a problem, it is important to note that some tools can be applied in a few minutes, as is the case with the FICA Questionnaire ${ }^{(36,40)}$. If the elderly report is not religious, the health professional should direct their questions to questions about what promotes a meaning and purpose in their life and how they understand their illness and the problems they are facing in order to investigate which beliefs can impact your treatment and prognosis ${ }^{(37)}$.

\section{Study limitations}

It is worth mentioning that this is a convenience sample, and this limitation was because there is no record of the total number of elderly family caregivers in the FHS areas. Thus, the study was based on indications, which can lead to bias, mainly because there was no participant who presented forms of negative coping or carelessness to the family member. The study was carried out among family caregivers of low-income elderly people in a middle-eastern city of Brazil. We must take care in order not to extrapolate these findings to other contexts.

\section{Contributions to the area of nursing, health and public policies}

The results of this study bring as contributions to professional practice evidences that awaken the professional to integrate the spiritual dimension to clinical practice, considering the importance of this practice during the aging process. For the formation, the study reinforces the relevance of the theme of spirituality being transversal to undergraduate and postgraduate curricula of health professionals. The findings reinforce the need for public policies to care for the family caregiver of the elderly, especially the elderly who cares for another elderly person at home.

\section{FINAL CONSIDERATIONS}

This study explains the stress situations that the elderly caregivers of an elderly family member pass; the little support received from the $\mathrm{PHC}$ service; and that $\mathrm{R} / \mathrm{S}$ is the main coping strategy employed to cope with daily stress relief. The $\mathrm{PHC} /$ FHS service plays an essential role in the care, functioning as a support to the elderly family caregivers and to the elderly relatives of the caregivers.

We hope that the spiritual dimension will be considered as an auxiliary element in the healthcare process. At this stage of life, spirituality is pronounced, as the elderly person is introspective, thoughtful and evaluative throughout his life. It is necessary to foster new research in order to recognize the needs of this population and to develop support strategies.

\section{REFERENCES}

1. Butler R. The longevity revolution: the benefits and challenges of living a long life. US: PublicAffairs; 2010.

2. Lee R. Population Aging and the Changing Economic Life Cycle: A Global Perspective. In: Challenges of Aging[Internet]. London: Palgrave Macmillan UK; 2015[cited 2017 Apr 25]. p. 31-46. Available from: http://link.springer.com/10.1057/9781137283177_3 
3. United Nations Population Division. Department of Economic and Social Affairs. Population Ageing and Development: 2012[Internet]. New York: UN; 2012[cited 2017 Apr 25]. Available from: http://www.un.org/en/development/desa/population/publications/ageing/ population-ageing-development-2012.shtml

4. Brasil. Instituto Brasileiro de Geografia e Estatística-IBGE. Sinopse do senso demográfico. Projeção da pop. Brasil por sexo e idade 2000-2060; Projeção da população das UF por sexo e idade 2000-2030.[Internet]. Rio de Janeiro; 2013 [cited 2017 Apr 25]. Available from: http://www.ibge.gov.br/home/estatistica/populacao/projecao_da_populacao/2013/

5. Oliveira MAC, Pereira IC.[Primary health care essential attributes and the family health strategy]. Rev Bras Enferm[Internet]. 2013[cited 2017 Apr 18];66(Spec):158-64. Available from: http://www.ncbi.nlm.nih.gov/pubmed/24092323 Portuguese

6. Santos CTB, Andrade LOM, Silva MJ, Sousa MF. Percurso do idoso em redes de atenção à saúde: um elo a ser construído. Physis Rev Saúde Colet[Internet]. 2016[cited 2017 Apr 25];26(1):45-62. Available from: http://www.scielo.br/pdf/physis/v26n1/01037331-physis-26-01-00045.pdf

7. Couto A, Castro EAB, Caldas CP. Experiences to be a family caregiver of dependent elderly in the home environment. Northeast Netw Nurs J[Internet]. 2016[cited 2017 May 1];17(1):76-85. Available from: http://200.129.29.202/index.php/rene/article/view/2608

8. Oliveira M, Boaretto M, Vieira L. A percepção do cuidador familiar de idosos dependentes sobre o papel do profissional da saúde em sua atividade. Ciênc Biol Saúde[Internet]. 2015[cited 2017 Apr 25];35(2):81-90. Available from: http://www.uel.br/revistas/ uel/index.php/seminabio/article/view/19157

9. Pereira LSM, Soares SM.[Factors influencing the quality of life of family caregivers of the elderly with dementia]. Ciênc Saude Colet[Internet]. 2015[cited 2017 Apr 25];20(12):3839-51. Available from: http://www.scielo.br/pdf/csc/v20n12/1413-8123csc-20-12-3839.pdf Portuguese

10. Schuck LM, Antoni C. Resiliência e vulnerabilidade no cuidado com o idoso dependente: um estudo de caso. Temas Psicol[Internet]. 2014[cited 2017 May 1];22(4):941-51. Available from: http://pepsic.bvsalud.org/pdf/tp/v22n4/v22n04a20.pdf

11. Luchesi BM, Souza ÉN, Gratão ACM, Gomes GAO, Inouye K, Alexandre TS, et al. The evaluation of perceived stress and associated factors in elderly caregivers. Arch Gerontol Geriatr[Internet]. 2016[cited 2017 Sep 2];67:7-13. Available from: http://linkinghub. elsevier.com/retrieve/pii/S0167494316301182

12. Lavela SL, Ather N. Psychological health in older adult spousal caregivers of older adults. Piette J, (Ed.). Chronic Illn[Internet]. 2010[cited 2017 Apr 25];6(1):67-80. Available from: http://www.ncbi.nlm.nih.gov/pubmed/20308352

13. Vieira L, Nobre JRS, Tavares KO, Bastos CCBC. Cuidar de um familiar idoso dependente no domicílio: reflexões para os profissionais da saúde. Rev Bras Geriatr Gerontol[Internet]. 2012[cited 2017 Apr 25];15(2):255-64. Available from: http://www.scielo.br/pdf/ rbgg/v15n2/08.pdf

14. Silva KM, Santos SMA, Souza AIJ. Reflexões sobre a necessidade do cuidado humanizado ao idoso e ao familiar cuidador. Saúde Transform Soc[Internet]. 2015[cited 2017 Apr 25];5(3):20-4. Available from: http://stat.ijie.incubadora.ufsc.br/index.php/ saudeetransformacao/article/view/2423

15. Andrade LM, Sena ELS, Pinheiro GML, Meira EC, Lira LSSP.[Public policies for the elderly in Brazil: an integrative review]. Ciênc Saúde Colet[Internet]. 2013[cited 2017 May 9]; 18(12):3543-52. Available from: http://www.ncbi.nlm.nih.gov/pubmed/24263871 Portuguese

16. Corbin J, Strauss A. Pesquisa qualitativa: técnicas e procedimentos para o desenvolvimento de teoria fundamentada. Rocha LO, (Trad.). Porto Alegre: Artmed; 2008.

17. Brasil. Instituto Brasileiro de Geografia e Estatística-IBGE. Diretoria de Pesquisas - DPE - Coordenação de População e Indicadores Sociais - COPIS. Censo: informações das cidades[Internet]. Juiz de Fora; 2014[cited 2017 Apr 25]. Available from: http://cod.ibge. gov.br/7PF

18. Brasil. Instituto Brasileiro de Geografia e Estatística-IBGE. Ministério do Planejamento. Distribuição da população por sexo, segundo os grupos de idade - Juiz de Fora.[Internet]. Brasília; 2010[cited 2017 Apr 25]. Available from: http://brasilemsintese.ibge.gov.br/ populacao/populacao-por-sexo-e-grupo-de-idade-2010.html

19. Brasil. Instituto Brasileiro de Geografia e Estatística-IBGE. Dir. Pesquisas - DPE - Coordenação de População e Indicadores Sociais - COPIS. Sinopse do senso demográfico. Distribuição da população por município, bairros - Juiz de Fora.[Internet]. Brasília; 2010[cited 2017 Apr 25]. Available from: http://cod.ibge.gov.br/7PF

20. Panzini RG, Bandeira DR. Spiritual-Religious Coping Scale (Srcope Scale): Elaboration and Construct Validation. Psicol em Estud[Internet]. 2005[cited 2017 Apr 25];10:507-16. Available from: http://www.scielo.br/pdf/pe/v10n3/v10n3a18.pdf

21. Pargament KI, Koenig HG, Perez LM. The many methods of religious coping: development and initial validation of the RCOPE. J Clin Psychol[Internet]. 2000[cited 2017 May 1];56(4):519-43. Available from: http://www.ncbi.nlm.nih.gov/pubmed/10775045

22. Dionne-Odom JN, Lyons KD, Akyar I, Bakitas MA. Coaching family caregivers to become better problem solvers when caring for persons with advanced cancer. J Soc Work End Life Palliat Care[Internet]. 2016[cited 2017 Apr 25];12(1-2):63-81. Available from: http://www.tandfonline.com/doi/full/10.1080/15524256.2016.1156607

23. Koenig HG, Pargament KI, Nielsen J. Religious coping and health status in medically ill hospitalized older adults. J Nerv Ment Dis[Internet]. 1998[cited 2017 Apr 25];186(9):513-21. Available from: http://www.ncbi.nlm.nih.gov/pubmed/9741556 
24. Koenig HG. Religion, Spirituality, and Health: the research and clinical implications. ISRN Psychiatry[Internet]. 2012[cited 2017 May 9];2012:1-33. Available from: http://www.ncbi.nlm.nih.gov/pubmed/23762764

25. Moreira-Almeida A, Lucchetti G. Panorama das pesquisas em ciência, saúde e espiritualidade. Cienc Cult[Internet]. 2016[cited 2017 May 9];68(1):54-7. Available from: http://cienciaecultura.bvs.br/pdf/cic/v68n1/v68n1a16.pdf

26. Koenig H, King D, Carson VB. Handbook of religion and health. USA: Oxford University Press; 2012.1186 p.

27. Chaves LJ, Gil CA. Older people's concepts of spirituality, related to aging and quality of life. Ciênc Saúde Colet[Internet]. 2015[cited 2017 May 9];20(12):3641-52. Available from: http://www.scielo.br/pdf/csc/v20n12/en_1413-8123-csc-20-12-3641.pdf

28. Kim S-S, Kim-Godwin YS, Koenig HG. Family spirituality and family health among Korean-American elderly couples. J Relig Health[Internet]. 2016[cited 2017 Apr 25];55(2):729-46. Available from: http://link.springer.com/10.1007/s10943-015-0107-5

29. Moreira-Almeida A, Lotufo Neto F, Koenig HG. Religiousness and mental health: a review. Rev Bras Psiquiatr[Internet]. 2006[cited 2017 Apr 25];28(3):242-50. Available from: http://www.ncbi.nlm.nih.gov/pubmed/16924349

30. Lutgendorf SK, Russell D, Ullrich P, Harris TB, Wallace R. Religious Participation, Interleukin-6, and Mortality in Older Adults. Heal Psychol[Internet]. 2004[cited 2017 Apr 25];23(5):465-75. Available from: http://www.ncbi.nlm.nih.gov/pubmed/15367066

31. Sephton SE, Koopman C, Schaal M, Thoresen C, Spiegel D. Spiritual expression and immune status in women with metastatic breast cancer: an exploratory study. Breast J[Internet]. 2001[cited 2017 Apr 25];7(5):345-53. Available from: http://www.ncbi.nlm. nih.gov/pubmed/11906445

32. Abdala GA, Kimura M, Duarte YAO, Lebrão ML, Santos B. Religiousness and health-related quality of life of older adults. Rev Saúde Pública[Internet]. 2015[cited 2017 Apr 18];49:1-9. Available from: http://www.ncbi.nlm.nih.gov/pubmed/26274870

33. Lucchetti G, Lucchetti AG, Badan-Neto AM, Peres PT, Peres MFP, Moreira-Almeida A, et al. Religiousness affects mental health, pain and quality of life in older people in an outpatient rehabilitation setting. J Rehabil Med[Internet]. 2011 [cited 2017 Apr 25];43(4):316-22. Available from: http://www.medicaljournals.se/jrm/content/?doi = 10.2340/16501977-0784

34. Agli O, Bailly N, Ferrand C. Spirituality and religion in older adults with dementia: a systematic review. Int Psychogeriatrics[Internet]. 2015[cited 2017 Apr 18];27(5):715-25. Available from: http://www.ncbi.nlm.nih.gov/pubmed/25155440

35. Seima MD, Lenardt MH, Caldas CP.[Care relationship between the family caregiver and the elderly with Alzheimer]. Rev Bras Enferm[Internet]. 2014[cited 2017 Apr 25];67(2):233-40. Available from: http://www.ncbi.nlm.nih.gov/pubmed/24861066 Portuguese

36. Moreira-Almeida A, Koenig HG, Lucchetti G. Clinical implications of spirituality to mental health: review of evidence and practical guidelines. Rev Bras Psiquiatr[Internet]. 2014[cited 2017 Apr 25];36(2):176-82. Available from: http://www.ncbi.nlm.nih.gov/ pubmed/24839090

37. Koenig H. Espiritualidade no cuidado com o paciente: por quê, como, quando e o quê. São Paulo: FE[Internet]. 2005 [cited 2017 Apr 25]. Available from: http://www.academia.edu/download/31331669/-A-espiritualidade-no-cuidado-com-o-paciente.pdf

38. Menegatti-Chequini MC, Gonçalves JPB, Leão FC, Peres MFP, Vallada H. A preliminary survey on the religious profile of Brazilian psychiatrists and their approach to patients' religiosity in clinical practice. BJPsych Open[Internet]. 2016 [cited 2017 Apr 25];2(6):346-52. Available from: http://bjpo.rcpsych.org/lookup/doi/10.1192/bjpo.bp.116.002816

39. Tostes JSR, Pinto AR, Moreira-Almeida A. Religiosidade/Espiritualidade na prática clínica: o que o psiquiatra pode fazer? Debates Psiquiatr [Internet]. 2013[cited 2017 Apr 25];3(2):20-6. Available from: http://www.abp.org.br/portal/ religiosidadeespiritualidade-na-pratica-clinica-o-que-o-psiquiatra-pode-fazer/

40. Puchalski C, Romer AL. Taking a spiritual history allows clinicians to understand patients more fully. J Palliat Med[Internet]. 2000[cited 2017 Apr 25];3(1):129-37. Available from: http://www.liebertonline.com/doi/abs/10.1089/jpm.2000.3.129 